慶應義塾大学学術情報リポジトリ

Keio Associated Repository of Academic resouces

\begin{tabular}{|c|c|}
\hline Title & Antihypertensive action of melatonin in the spontaneously hypertensive rat \\
\hline \multicolumn{2}{|l|}{ Sub Title } \\
\hline Author & $\begin{array}{l}\text { 川島, 紘一郎(Kawashima, Koichiro) } \\
\text { 三輪, 裕子(Miwa, Yuko) } \\
\text { 藤本, 和子(Fujimoto, Kazuko) } \\
\text { 大畑, 尚代(Ohata, Hisayo) } \\
\text { 西野, 弘四(Nishino, Hiroshi) } \\
\text { 小池，博之(Koike, Hiroyuki) }\end{array}$ \\
\hline Publisher & 共立薬科大学 \\
\hline Publication year & 1987 \\
\hline Jtitle & $\begin{array}{l}\text { 共立薬科大学研究年報 (The annual report of the Kyoritsu College of } \\
\text { Pharmacy). No.32 (1987. ) ,p.71-71 }\end{array}$ \\
\hline \multicolumn{2}{|l|}{ JaLC DOI } \\
\hline \multicolumn{2}{|l|}{ Abstract } \\
\hline Notes & 抄録 \\
\hline Genre & Technical Report \\
\hline URL & $\begin{array}{l}\text { https://koara.lib.keio.ac.jp/xoonips/modules/xoonips/detail.php?koara_id=AN00062898-0000003 } \\
\text { 2-0071 }\end{array}$ \\
\hline
\end{tabular}

慶應義塾大学学術情報リポジトリ(KOARA)に掲載されているコンテンツの著作権は、それぞれの著作者、学会または出版社/発行者に帰属し、その権利は著作権法によって 保護されています。引用にあたっては、著作権法を遵守してご利用ください。

The copyrights of content available on the KeiO Associated Repository of Academic resources (KOARA) belong to the respective authors, academic societies, or publishers/issuers, and these rights are protected by the Japanese Copyright Act. When quoting the content, please follow the Japanese copyright act. 


\title{
Antihypertensive Action of Melatonin in the Spontaneously Hypertensive Rat
}

\author{
Koichiro Kawashima, Yuko Miwa, Kazuko Fujimoto, Hisayo Oонata, \\ Hiroshi Nishino* and Hiroyuki Korke* \\ 川島紘一郎, 三輪裕子, 藤本和子, 大畑尚代, 西野弘四*, 小池博之*
}

The effects of melatonin on blood pressure and heart rate were studied in 23-week-old male spontaneously hypertensive rats. Melatonin infused i.p. at a dose of $6 \mathrm{mg} / \mathrm{rat}$ per day for 5 days using an osmotic minipump produced a significant reduction of blood pressure and a slight but significant decrease of heart rate in the conscious and unrestrained state. These cardiovascular effects of melatonin developed gradually. Plasma renin concentration tended to decrease after melatonin treatment. These results demonstrate thet melatonin has an antihypertensive action. The mechanism of the antihypertensive action of melatonin requires further study.

本報告は Clin. Exp. Hyper., A 9, 1121-1131（1987）に発表.

* 三共中央研究所 